\title{
胸部大動脈手術後の仮性動脈瘤に対するステント グラフト内挿術による再手術の有用性
}

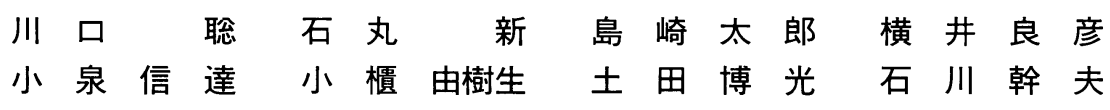

\begin{abstract}
胸部大動脈手術後に発生した仮性大動脈瘤 10 例を対象として, ステントグラフト内挿術の有用性と 問題点について検討を加えた。手術は全例全身麻酔下に総大腿動脈より経血管的にシースを介してス テントグラフトを内挿した。 術後 2 週間以内に瘤内が血栓化したものは 10 例中 7 例 $(70 \%)$ であり, これを初期成功とした. 残り 3 例では瘤内に少量の血流（minor endoleak）を認め, このうち 1 例 は 6 カ月後にステントグラフトが移動し外科的修復を要した。また, 2 例を大量喀血により失った. 胸部大動脈手術後の人工血管吻合部に発生した仮性瘤に対する再手術は，全身管理や手術手技に困難 を伴うことが多く，低侵襲治療であるステントグラフト内抙術の有用性は高いと考えられる. しか し, 喀血例への対策, および遠隔期成績については, 今後の十分な検討が必要である. 日心外会誌 28 巻 4 号 : 232-236 (1999)
\end{abstract}

Keywords：ステント，ステントグラフト，血管内手術，仮性動脈瘤，胸部大動脈瘤

\begin{abstract}
Feasibility of Endovascular Stent Graft Repair for Redo Operation of Pseudoaneurysms after Thoracic Aortic Surgery

Satoshi Kawaguchi, Shin Ishimaru, Tarou Shimazaki, Yoshihiko Yokoi, Nobusato Koizumi, Yukio Obitsu, Hiromitsu Tsuchida and Mikio Ishikawa (Department of Surgery II, Tokyo Medical University, Tokyo, Japan)

Ten cases of pseudoaneurysms that developed after thoracic aortic surgery were treated with an endovascular technique using stent grafts for redo operations. All patients were treated under general anesthesia and the stent grafts were implanted through $18 \mathrm{Fr}$ or $20 \mathrm{Fr}$ sheath introducers via femoral arteries under fluoroscopic guidance. The stent graft was composed of several units of self-expanding stainless-steel $Z$ stents covered with an ultra-thin polyester fabric. Stent graft deployment was technically successful in all patients and in 7 of 10 cases exclusion of the aneurysms with no endoleak was achieved within two weeks after the operation (initial success rate: $70 \%$ ). Minor endoleak was found in 3 patients and one of those finally underwent conventional surgery because of stent graft migration 6 months after the stent graft repair. Two of ten patients died, 10 days and 18 weeks after the operation, due to hemoptysis, which had already been observed before the operation. Endovascular stent graft repair of pseudoaneurysms after thoracic aortic surgery is a minimally invasive operation in comparison with conventional redo surgery with extracorporeal circulation. These results and experiences suggest that stent graft repair can be a safe and useful redo treatment for pseudoaneurysms. However, careful long-term investigations are necessary to prove the value and effect of this endovascular treatment and a new strategy for cases with hemoptysis is required. Jpn. J. Cardiovasc. Surg. 28 : 232-236 (1999)
\end{abstract}

胸部大動脈瘤に対する外科手術としてパッチ形 成術や人工血管置換術があるが, 術後遠隔期に仮 性瘤を形成した場合, その再手術については全身 状態不良や到達経路の確保困難, 再度の体外循環 などのリスクを伴うことが多い.このことから最 近では，経血管的に治療が可能でより低侵襲であ

1998 年 5 月 7 日受付，1998 年 12 月 29 日採用

東京医科大学第 2 外科 $₹ 160-0023$ 東京都新宿区西新宿 6-7-1
るステントグラフト内插術の導入が期待されてい る。しかし現時点で臨床応用の報告は散見される にすぎず1 5)，本法の成績や有用性について十分 な検討はなされていない. 今回, 教室で経験した 胸部仮性大動脈瘤に対するステントグラフト内挿 術の有用性を検討したので報告する。 


\section{対象および方法}

1995 年 2 月より 1998 年 2 月までの間にステン トグラフト内挿術を施行した胸部大動脈瘤は 57 例（大動脈解離 23 例を含む）であり，このうち 初回手術としてのパッチ形成術あるいは人工血管 置換術後に仮性動脈瘤を形成した 10 例を検討対 象とした (表 1)。平均年齢は69.4 7.2 歳 （55７8 歳）であり，男性：女性は $7: 3$ であっ た。

初回手術は囊状瘤に対して瘤切除およびパッチ 形成術を行った 6 例，遠位下行大動脈の真性瘤に 対して人工血管置換術を施行した 1 例，大動脈縮 窄症に対して人工血管置換術を施行した 1 例，ま た大動脈解離に対してエントリー閉鎖を目的とし たパッチ形成術あるいは人工血管置換術を施行し た 2 例の合計 10 症例であった。再手術までの期 間は平均 $9.3 \pm 11.1$ 年（1〜 40 年）であった。

手術は透視および digital subtraction angiography（以下DSA）が可能な手術室で全身麻酔 下に施行し，右上腕動脈から大腿動脈に通したガ イドワイヤーを牽引して緊張させ, その誘導下に 大腿動脈切開部より 18 Fr.あるいは $20 \mathrm{Fr}$.のステ ントグラフト運搬用テフロンシースを病変部まで 挿入し (tug of wire 法) ${ }^{4)}$, 同シースを介してス テントグラフトを内挿した。動脈瘤の起始部が左 総頸動脈分岐部に近い 1 例では，ステントグラフ トの中枢側固定に伴う左総頸動脈の血流遮断を想 定して，術前に右総頸一左総頸動脈バイパス術を
施行した。

使用したステントグラフトは自己拡張型 Gianturco Z stent ${ }^{\circledR}$ （Cook 社製）を骨格とし， その周囲を極薄平織りポリエステル布で被覆固定 し作製した（図 1)。被覆用ポリエステルは厚さ $0.1 \mathrm{~mm}$ で, 前期 5 例に対しては有孔性 $2,500 \sim 3,000$, 後期 5 例に対しては有孔性 200〜250を使用した。

術後の瘤内あるいは偽腟内への血流残存（endoleak）の有無および瘤内血栓化について DSA および造影 CT を用いて評価し, 術後 2 週間以内 に endoleak が消失したものを初期成功（initial success), endoleak が残存するが血流が十分に 減少し，減圧が期待できるものを minor endoleak，また術前とほぼ同様の血流を認め減圧 効果が期待できないものを major endoleak とし

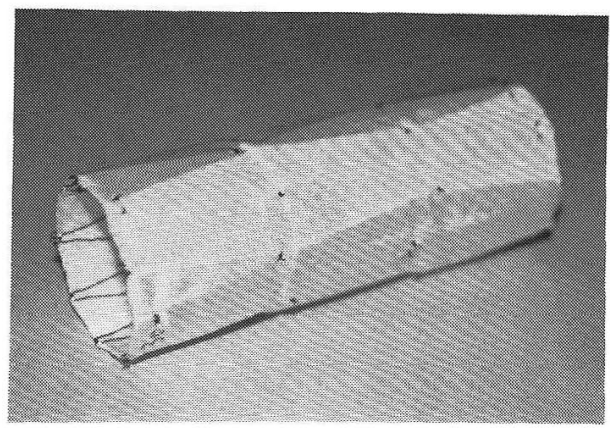

図 1 ステントグラフト

自己拡張型 Zステントを極薄平織りポリエステル布 で被覆し作製した。

表 1 対 象 症 例

\begin{tabular}{|c|c|c|c|c|c|c|}
\hline No. & 年齢 & 性別 & 主訴 & 瘤部位 & 瘤径 & 瘤発生部位 \\
\hline 1 & 74 & 男性 & 喀血 & 遠位弓部 & 52 & 真性瘤パッチ形成部 \\
\hline 2 & 65 & 男性 & 瘤拡大 & 遠位弓部 & 52 & 真性溜パッチ形成部 \\
\hline 3 & 71 & 男性 & 瘤拡大 & 下行近位 & 64 & 解離エントリー閉鎖部 \\
\hline 4 & 78 & 男性 & 喀血 & 下行近位 & 58 & 真性瘤パツチ形成部 \\
\hline 5 & 55 & 女性 & 瘤掋大 & 下行近位 & 42 & 大動脈縮窄症人工血管吻合部 \\
\hline 6 & 62 & 男性 & 喀血 & 下行遠位 & 68 & 真性瘤パッチ形成部 \\
\hline 7 & 70 & 男性 & 喀血 & 下行遠位 & 52 & 真性瘤人工血管吻合部 \\
\hline 8 & 68 & 男性 & 瘤拡大 & 下行遠位 & 58 & 解離人工血管吻合部 \\
\hline 9 & 78 & 女性 & 瘤拡大 & 下行遠位 & 41 & 真性溜パッチ形成部 \\
\hline 10 & 73 & 女性 & 瘤拢大 & 下行遠位 & 44 & 真性瘤パッチ形成部 \\
\hline
\end{tabular}


(A)

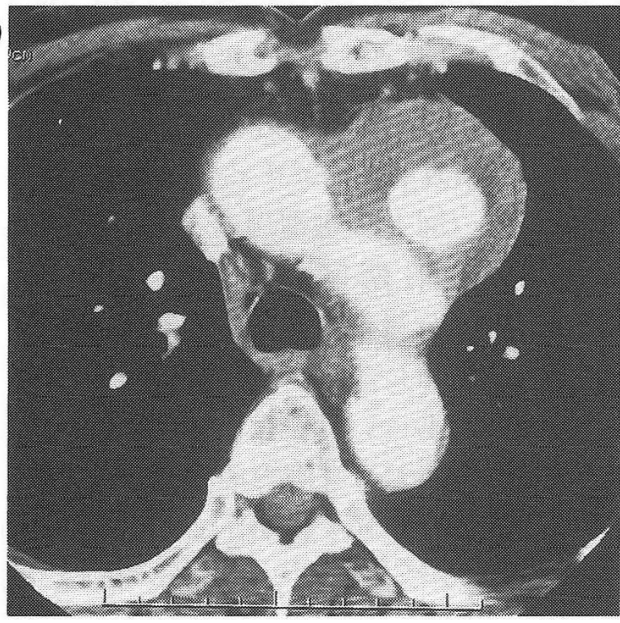

(B)

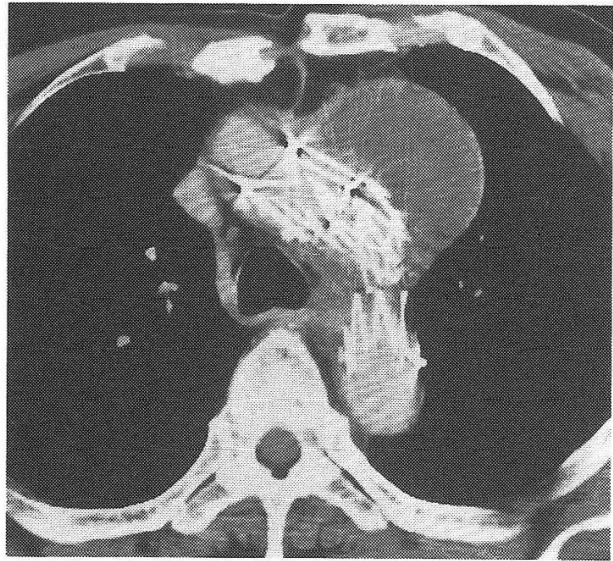

図 2 ステントグラフト内挿前 $(\mathrm{A}) ，$ 持よび内挿後 (B) CT 写真

遠位弓部大動脈瘤に対してステントグラフトを内㨀 し, 瘤内への血流遮断执よび瘤内血栓化に成功した。
た。

なお，手術は大学倫理委員会の規定に基づき， 本人および家族に対して予想される有效性と術中 および術後の合併症に関して十分な説明を行い， 同意を得たうえで施行した。

\section{結果}

初回達成は 10 例中 7 例（70\%）に得られ（図 2)， minor endoleak 3 例（30\%）に認めた。 また major endoleak は認めなかった（表2)。

表 2 結 果 1

\begin{tabular}{crr}
\hline Endoleak なし & 7 & $(70 \%)$ \\
Minor endoleak & 3 & $(30 \%)$ \\
Major endoleak & 0 & $(0 \%)$ \\
\hline 計 & 10 &
\end{tabular}

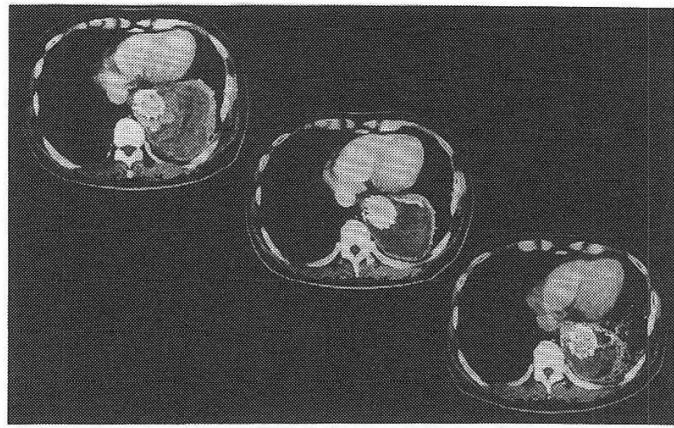

図 3 術後胸部 CT 写真

左より術後 1 週, 2 力月, 3 力月経過時の CT 写真. 動脈瘤の経時的な縮小が認められた。

表 3 結 果 2

\begin{tabular}{|c|c|c|c|c|}
\hline No. & Endoleak & 転帰 & 術後観察期間 & 備考 \\
\hline 1 & minor & 咯血により死亡 & $10 \mathrm{H}$ & \\
\hline 2 & なし & 経過良好 & 14 力月 & \\
\hline 3 & minor & stent graft migration & 16 力月 & 再于術 \\
\hline 4 & minor & 血栓化進行, 喀血消失 & 9 力月 & \\
\hline 5 & なし & 経過良好 & 2 力月 & \\
\hline 6 & なし & 喀血により死亡 & 4 力月 & \\
\hline 7 & なし & 経過良好, 喀血消失 & 11 力月 & \\
\hline 8 & なし & 経過良好 & 3 力月 & \\
\hline 9 & なし & 経過良好 & 1 力月 & \\
\hline 10 & なし & 経過良好 & 5 日 & \\
\hline
\end{tabular}


Minor endoleak を認めた 3 例のうち 1 例は，術 直後より近位下行大動脈の屈曲部小弯側の瘤内に endoleak を認め, 術後約 6 カ月でステントグラ フトが瘤内に移動（migration）し，外科手術を 余儀なくされた，他の 2 例はステントグラフト固 定部中枢側からの leak であり，2 例のうち 1 例 は 1 週間後に血栓化進行に伴い主訴である喀血が 消失した．死亡した 2 例はいずれも術前より認め た喀血が術後も持続し，このうち 1 例は endoleak 認め術後第 10 病日に, 他の 1 例は endoleak はなく瘤の縮小傾向を認めたものの（図 3), 術後 4 力月目にいずれも大量喀血を原因とし て死亡した（表3）。

\section{考察}

大動脈疾患に対する外科治療後にみられる合併 症として，人工血管吻合部あるいはパッチ形成部 から発生する仮性動脈瘤がある。発生原因として 吻合部の過度の緊張, 吻合部感染, また縫合系と して用いた絹糸などが指摘されている ${ }^{9 \sim 12)}$. 初回 手術から仮性動脈瘤発見までの期間は比較的長く 自験例では平均 9.3 年であり, 他の報告でも平均 $5.9 \sim 15.2$ 年であった ${ }^{12 \sim 16)}$.

吻合部仮性動脈留は末梢動脈に多く発生し11), 再手術は比較的容易であるが，特に胸部大動脈に 発生した場合は全身状態が不良な他, 到達経路の 剥離操作や血流遮断部位の確保など手技的にも難 渋することが多い.

大動脈の拡張性病変に対するステントを応用し た血管内手術は，1969 年に米国の Dotter がコイ ルスプリングを用いた実験を行ったことから始ま る ${ }^{6)}$.その後いくつかの実験的検討を経て 90 年 代には腹部大動脈留に対して Parodiらが7), 胸 部大動脈瘤に対して Dake ら ${ }^{8)}$ がステントグラフ トの臨床使用を報告した。本邦でも，ステントグ ラフトを用いた血管内手術がその低侵襲性のゆえ に注目され始めており, 当教室では 1995 年 2 月 より現在までに胸部大動脈瘤 57 例, 腹部大動脈 瘤 26 例にステントグラフト内挿術を施行してき た。

本法は, 爯径部のみの切開により大腿動脈より 経血管的に病変部に人工血管を挿入するため, 病
変部への到達経路の剥離操作がいらず, また血管 吻合が不要で体外循環を必要とせず，特に胸部仮 性大動脈瘤に対する治療としては従来の手術と比 較して極めて低侵襲であり有用性が高いと思われ る.しかし，本法はステントのバネ張力で血管内 にグラフトを圧着させるため, 固定が不十分であ ると瘤内への endoleak を生ずることになり, 確 実性において吻合法に劣る. Minor endoleakを 認めた 2 例についてはステントグラフト中枢側固 定部からの leak が原因であると考えられ, 固定 すべき瘤中枢側健常血管（鎖骨下動脈分岐部から 瘤起始部）の長さが短く不十分であった。また， migrationについても, 中枢側健常血管への不十 分な固定および瘤内へのステントグラフト変移が 原因であったと考えられ，これらの経験から著者 らは migrationの予防方法として拡張バルーン を用いてステントグラフトを血管内壁に確実に圧 着させることが有効であると考えている.

胸部大動脈瘤による喀血の原因について剖検に よる報告では, 肺の動脈瘤癒着部に糜燗，壊死を 形成し, 強い炎症細胞浸潤を認めることが多く, 大動脈瘤による肺，気管支壁の圧排とそれによる 壁の慢性炎症性変化，壊死，あるいは二次感染の 合併による壁の脆弱化が引き起こす大動脈肺気管 支㿉が考えられている17 22). 今回の検討症例中 4 例が喀血を主訴としており，このうち大量喀血に より死亡した 2 例についてみると, 術前より認め られた喀血がステントグラフト内挿術後も持続 し，特に瘤の縮小傾向を認めたにもかかわらず喀 血を来した 1 例もあったことから，その原因とし て肺への炎症波及による気管支動脈からの出血も 否定できない，喀血は動脈瘤破裂の前兆の一つで あり早急な治療が必要であるが17)，ステントグラ フト内挿術後に喀血が持続した場合には注意が必 要であり, 大動脈気管支瘦の存在の可能性もある ことから, 仮性動脈瘤, 㾇部の切除といった根治 的治療を考慮すべきである.

胸部仮性大動脈留に対するステントグラフト内 挿術は低侵襲性以えに有用性は高いと考えられる が，本法の遠隔成績については十分な検討がな く，本法の先駆考である Mitchell らの観察期間 も平均 12.6 力月と短 ${ }^{23)}$, 未知の合併症の存在 
を否定することはできず，今後の遠隔成績の検討 が必要であると考えられる。

\section{結語}

1. 胸部大動脈の外科手術後に発生した仮性大 動脈瘤 10 例に対してステントグラフト内挿術を 施行した。

2. 治療成績は初回達成 $70 \%$, minor endoleak 30\%であり, major endoleak は認めなか った.

3. 胸部仮性大動脈瘤に対する再手術としてス テントグラフト内挿術の有用性が示唆された。

4. 喀血例に対しては瘤内血栓化に成功して も，その喀血が持続する場合，より根治的な治療 が必要である。

\section{文献}

1）加藤雅明, 打田日出夫, 吉川公彦ほか：メタリッ ク・ステント update 大動脈瘤. 画像診断 16 ： 525-529, 1996.

2）石丸 新：大動脈瘤治療の最近のトピックス 血 管内治療 (endovascular surgery)一外科上り. カレントテラピー 14:118-122, 1996.

3）石丸 新, 川口 聡：ステントグラフトによる大 動脈瘤の治療. IVR 12：205-208, 1997.

4）川口 聡, 石丸 新, 小泉信達ほか：DeBakey III $\mathrm{b}$ 型大動脈解離に対するステントグラフト内捚術 2 症例の経験. 日胸外会誌 45：926-933, 1997.

5）緑川博文, 星野俊一, 猪狩次雄ほか：胸部下行大 動脈瘤に対しステントグラフト内㨂術を施行し た高安動脈炎の 1 例. 日血外会誌 $6: 835-839$, 1997.

6) Dotter, C. T.: Transluminally-placed coilspring endarterial tube graft. Long-term patency in canine popliteal artery. Invest. Ragiol. 4: 329-332, 1969.

7) Parodi, J. C., Palmaz, J. C. and Barone, H. D. : Transfemoral intraluminal graft implantation for abdominal aortic aneurysms. Ann. Vasc. Surg. 5 : 491-499, 1991.

8) Dake, M. D., Miller, D. C., Semba, C. P. et al. : Transluminal placement of endovascular stentgrafts for the treatment of descending thoracic aortic aneurysms. N. Eng. J. Med. 331 : 17291734, 1994.

9) Richardson, J. V. and MacDowell, H. A., Jr. : Anastomotic aneurysms following arterial grafting: A ten-year experience. Ann. Surg. 184: 179-182, 1976.

10) Moore, W. S. and Holl, A. D. : Late suture failure in the pathogenesis of anastomotic false aneurysms. Ann. Surg. 172: 1064-1068, 1970.

11）浅野献一：胸部下行大動脈瘤術後の仮性大動脈 瘤. 外科診療 23 : 1483-1485, 1981.

12) Sato, O., Tada, Y., Miyata, T. et al.: False aneurysms after aortic operations. J. Cardiovasc. Surg. 33 : 604-608, 1992.

13) Read, C. R. and Thompson, B. W. : Uninfected anastomotic false aneurysms following arterial reconstruction with prosthetic grafts. J. Cardiovasc. Surg. 16: 558-561, 1975.

14) Gaylis, H.: Pathogenesis of anastomotic aneurysms. Surgery 90 : 509-515, 1981.

15) Dennis, J. W., Littooy, F. N., Greister, H. P. et al.: Anastomotic pseudoaneurysms. Arch. Surg. 121 : 314-317, 1986.

16) Treiman, G. S., Weaver, F. A., Cossman, D. V. et al.: Anastomotic false aneurysms of the abdominal aorta and the iliac arteries. J. Vasc. Surg. 8: 268-273, 1988.

17）石川 浩, 星 秀逸, 小川純一ほか：喀血を主訴 とした胸部大動脈瘤切迫破裂の 2 例. 気管支学 16 : 206-210, 1994.

18) Guidetti, A. S., Pik, A., Peer, A. et al. : Haemoptysis as the sole presenting symptom of dissection of the aorta. Thorax 44: 444-445, 1989.

19) Wheeler, A. P. and Loyd, J. E. : Fatal homoptysis: Aortobronchial fistula as a preventable cause of death. Crit. Care Med. 17 : 1228-1230, 1989.

20) Miyazaki, M., Hiraga, S., Kitamura, M. et al. : Aortobronchial fistula complicated with an aortic aneurysm in hemodialysis patient. Nephron 56: 101-102, 1990.

21) Villar, M. T. A., Wiggins, J., Corrin, B. et al. : Recurrent and fatal haemoptysis caused by an atheromatous abdominal aortic aneurysm. Thorax 45: 568-569, 1990.

22) Cry, J. A. S., Ward, H. B. and Molina, J.E. : Correction of thoracic aortic aneurysmbronchial fistula. J. Card. Surg. 2: 109-113, 1987.

23) Mitchell, R. S., Dake, M. D., Semba, C. P. et al. : Endovascular stent-graft repair of thoracic aortic aneurysms. J. Thorac. Cardiovasc. Surg. 111 : 1054-1062, 1996. 